\title{
乾熱処理小麦澱粉の物理的特性
}

(2012 年 2 月 29 日受付 ; 2012 年 9 月 22 日採択)

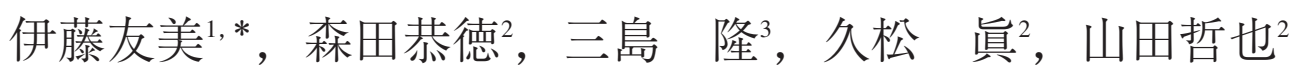

${ }^{1}$ 北海道教育大学教育学部旭川校 (070-8621 北海道旭川市北門町 9 丁目)

2 三重大学大学院生物資源学研究科 (514-8507 三重県津市栗真町屋町 1577)

3 三重大学大学院地域イノベーション学研究科 (514-8507 三重県津市栗真町屋町 1577)

\section{Physical Properties of Dry Heated Wheat Starch Granules}

Tomomi Ito, ${ }^{1, *}$ Yasunori Morita, ${ }^{2}$ Takashi Mishima, ${ }^{3}$ Makoto Hisamatsu ${ }^{2}$ and Tetsuya Yamada ${ }^{2}$

\begin{abstract}
${ }^{1}$ Hokkaido University of Education Asahikawa Campus (9-Hokumon-cho, Asahikawa, Hokkaido 070-8621, Japan) ${ }^{2}$ Graduate School of Bioresources, Mie University (1577 Kurimamachiya-cho, Tsu 514-8507, Japan)

${ }^{3}$ Graduate School of Regional Innovation Studies, Mie University (1577 Kurimamachiya-cho, Tsu 514-8507, Japan)
\end{abstract}

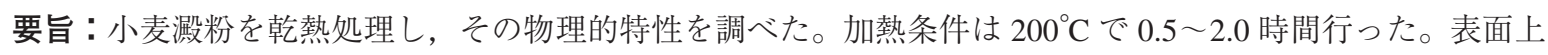
は, 何れの乾熱処理澱粉も澱粉粒子の変化はほとんどなかった。X 線回折と酵素感受性はコントロール (生 澱粉) と乾熱処理 $1 ， 2$ 時間との間に違いがみられた。DSC パターンは乾熱処理時間が長くなるほど糊化温 度が低温側に移行した。RVAによる粘度測定では，すべての乾熱処理澱粉でコントロールより著しく低下 しており，極限粘度も同様に低下していたことから，乾熱処理により外観では変化がみられないが，内部で は分子が著しく崩壞し, 低分子化が起こっていることが推察された。
\end{abstract}

キーワード：乾熱処理，物理的特性，小麦澱粉

古代より穀物や穀物粉を焼成 (焦がす) 処理すると消化 性が著しく向上することが知られており，現代でもこの方 法で処理したものが食品素材として広く市販されている。 したがって，穀物や穀物粉の乾熱処理については，その実 用性の高さから多くの研究がなされている(-3)。しかし，穀 物粉の主成分である澱粉を単独で乾熱処理した研究は案外 少ない。乾熱処理による澱粉の熱分解について詳細な総説 をTomasik らがが書いている。その中で, 歴史的には, 現 在も市販されている British-Gum がアイルランドのダブリ ンで大火があった際，貯蔵していた馬鈴著澱粉が焼け出さ れたため, その実用性が見出されたのが澱粉単独利用の始 まりだと記している。現在でも可溶性澱粉として試薬リス 卜に記載されているものは馬鈴著澱粉を乾熱処理して製造 しているとされている。しかし, 現在では, 食品素材や粘 性に着目した産業素材製造を目的として港粉をこの乾熱処 理で加工する際，一般に澱粉に無機酸または有機酸を加え ることで目的とする物質の製造が容易となるため，この方 法に関する研究が多いと Tomasik ら゙は述べている。した がって, Tomasikらは総説で, 澱粉の乾熱処理に関連する 報告は多くあっても, これらの研究結果を相互比較検討す ることができないといっている。すなわち，(1) 澱粉の植 物起源の相違, (2) 乾熱処理条件の相違 (温度, 保持時
間), (3) 初発水分の相違, (4) 添加物の種類と濃度 (酸の 種類等, 糖類, 脂質, タンパク質) 等が報告ごとに違って いることに起因する。事実，澱粉は植物起源により性質が 大きく異なることが知られている。したがって, 澱粉の種 類が異なれば共通した研究成果を示すことは期待されない ので, 個々の起源の澱粉についての研究が必要である。

筆者らはクッキー中の澱粉の形態について報告してき だが，この焼成工程で港粉は外見上も偏光十字も変化が ないものの，分子レベルでは低分子化していた。この研究 過程で添加する水分が少ない場合, 他の共存物質, 特に油 脂の影響に関心を抱き，これが焼成時に単なる熱媒体とし て働くだけなのか，また何らかの反応を澱粉との間で起こ して澱粉に影響を与えているのかを調べたの。白の結果, 油脂 (界面活性片) として用いたモノアシルグリセロール の脂肪酸の種類により澱粉分子の低分子化に差があること を見出した。しかし, 油脂が関与しない澱粉単独で乾熱処 理したものではどうなるのかを調べるため本実験を行っ た。Tomasik ら゙は総説で，一般に澱粉を乾熱処理した場 合 $200^{\circ} \mathrm{C}$ 以下の処理では熱分解生成物がほとんど検出され ないと述べているので, クッキー製造条件に準じて, 乾熱 処理を $200^{\circ} \mathrm{C}$ に設定し， $0.5 \sim 2.0$ 時間乾熱処理した小麦澱 粉粒の物理的特性について検討した。 


\section{1. 実験材料と実験方法}

\section{1) 試料調製}

試料澱粉は，グリコ栄養食品製の小麦澱粉を使用した。

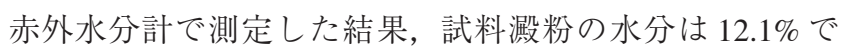
あった。この小麦澱粉 $(5 \mathrm{~g})$ をガラス製シャーレに平坦に なるように入れ，蓋をせずに， $200^{\circ} \mathrm{C}$ に設定した乾熱器 (STAC-NM，島津理化製) で $0.5 ， 1.0 ， 2.0$ 時間乾熱処理を 行った。これを乾熱処理澱粉とし, 生の小麦澱粉をコント ロールとした。

\section{2) X 線回折}

乾熱処理澱粉をアルミ板孔に埋設し，ミニフレックス (理学電機) で測定した。分析条件は, X 線源, $\mathrm{Cu}-\mathrm{K} \alpha$ 線 (ニッケルフィルター使用)； X 線管電圧， $30 \mathrm{kVp} ; \mathrm{X}$ 線管 電流, $10 \mathrm{~mA}$; 分散スリット, $1^{\circ}$; 制限スリット, $1^{\circ}$; 受 光スリット, 幅 $0.3 \mathrm{~mm} ;$ レートメーター, $1,000 \mathrm{cps}$; 走 査速度, $2 \% \mathrm{~min}$; 時定数, $1 \mathrm{~s}$; チャート速度, $20 \mathrm{~mm} / \mathrm{min}$ で行った。な拉，X線回折では水分含量が回折強度に強く 影響するので, 試料は水を張ったデシケーター中で一晚放 置してある程度水分含量を調製した後に測定した。

\section{3) グルコアミラーゼ感受性測定}

乾熱処理港粉 $(250 \mathrm{mg})$ を蒸留水 $(50 \mathrm{~mL})$ に懸濁し, グ ルコアミラーゼ液 (グルコアミラーゼ (生化学工業製) 1 mg $(32.6 \mathrm{U})$ を $10 \mathrm{~mL}$ の蒸留水に溶かし遠心分離 $(3,000$ $\left.\mathrm{rpm}, 10 \mathrm{~min}, 25^{\circ} \mathrm{C}\right)$ した上澄み) を $400 \mu \mathrm{L}$ 加え, $40^{\circ} \mathrm{C}$ で 24 時間まで反応させた。途中経時的に反応懸濁液を $5 \mathrm{~mL}$ ずつ採取し, 遠心分離 (3,000 rpm, $10 \mathrm{~min}$, 室温) 後, 沸 騰浴中で約 5 分間煮沸失活させ, 改良パーク・ジョンソン 法》で還元糖量を測定し, 下記の式によって加水分解率を 算出した。

加水分解率 $(\%)=\frac{\text { 反応で生じた還元糖量 }(\mathrm{mg})}{\text { 用いた試料澱粉量 }(\mathrm{mg})} \times 100$

\section{4) 示差走查熱量分析 (DSC)}

乾熱処理澱粉を前報らに準じ, DSC6100 (セイコー製) で測定した。

\section{5) 極限粘度の測定 ${ }^{8}$}

乾熱処理港粉を $1 \mathrm{M}$ 水酸化ナトリウム水溶液で溶解し, 0.05 0.50\%に希釈した。これをウベローデ型の毛細管粘 度計 (SIBATA，SU-72559) に注入し， $25^{\circ} \mathrm{C}$ の水槽中で約 10 分間放置後，試料溶液が毛細管を通過する時間を測定 した。測定は 5 回行い, その平均值を試料溶液の通過時間 $(t)$ とした。また, 水酸化ナトリウム溶液を用いたブラン クの通過時間を $t_{0}$ とした。溶媒の比重を $\rho_{0}$, 試料溶液の 比重を $\rho$ とすると相対粘度 ( $\left.\eta_{\mathrm{rel}}\right)\left[\right.$ [式 $\left.: \eta_{\mathrm{rel}}=\rho t / \rho_{\mathrm{o}} t_{0}\right]$ が得 られる(ただし希薄溶液であるので $\rho / \rho_{0}=1$ とした)。こ
の相対粘度 $\left(\eta_{\mathrm{rel}}\right)$ から 1 を減ずると比粘度 $\left(\eta_{\mathrm{sp}}\right)$ [式： $\eta_{\mathrm{sp}}$ $\left.=\eta_{\mathrm{rel}}-1\right]$ が得られる。この比粘度 $\left(\eta_{\mathrm{sp}}\right)$ は濃度 $(c)$ が高 くなるほど大きくなるので, 比粘度 $\left(\eta_{\mathrm{sp}}\right)$ を溶液濃度 $(c)$ で割って還元粘度 $\left(\eta_{\mathrm{red}}\right)\left[\right.$ 式 $: \eta_{\mathrm{red}}=\eta_{\mathrm{sp}} / c$ ] 求めた。こ の還元粘度 $\left(\eta_{\mathrm{red}}\right)$ を $X$ 軸に, 濃度 $(c)$ を $Y$ 軸にプロット し, 回帰方程式を求め, $c=0$ のときの $\eta_{\mathrm{red}}$ から, 極限 (固有) 粘度 $[\eta]$ を求めた。

\section{6) ラピッドビスコアナライザー $(\mathrm{RVA})^{9)}$}

乾熱処理澱粉に蒸留水を加えて $5 \%$ 懸濁液 (水分修正) にし，前報〕に準じて糊化特性試験装置 RVA (ニューポー トサイエンティフィック社製) で測定した。

\section{7) 膨潤度 $^{10)}$}

乾熱処理澱粉 $0.25 \mathrm{~g}$ に蒸留水 $10 \mathrm{~mL}$ 加えて懸濁させ, 15 時間放置後，容積から $1 \mathrm{~g}$ 当たりの膨潤度を算出した。

\section{2. 結果}

\section{1) $X$ 線回折による結晶特性}

乾熱処理澱粉の X 線回折図を Fig. 1 に示した。その結 果，コントロールと 0.5 時間処理ではほとんど結晶性の変 化は認められなかった。1.0 時間処理において，わずかに ピークの消失が認められたが，2.0 時間処理ではコント ロールにみられた 4 本の主なピークがかなり消失し, 図形 が不鮮明となった。

\section{2) 酵素感受性試験}

乾熱処理澱粉の酵素感受性試験の結果を Fig. 2 に示し た。その結果， 0.5 時間処理ではコントロールと変わらず, ほとんど分解しなかった。 1.0 時間处理と 2.0 時間処理で はX線回折に扔いて結晶性の保持に差がみられたにもか かわらず，酵素感受性ではどちらも 24 時間で約 $23 \%$ と,

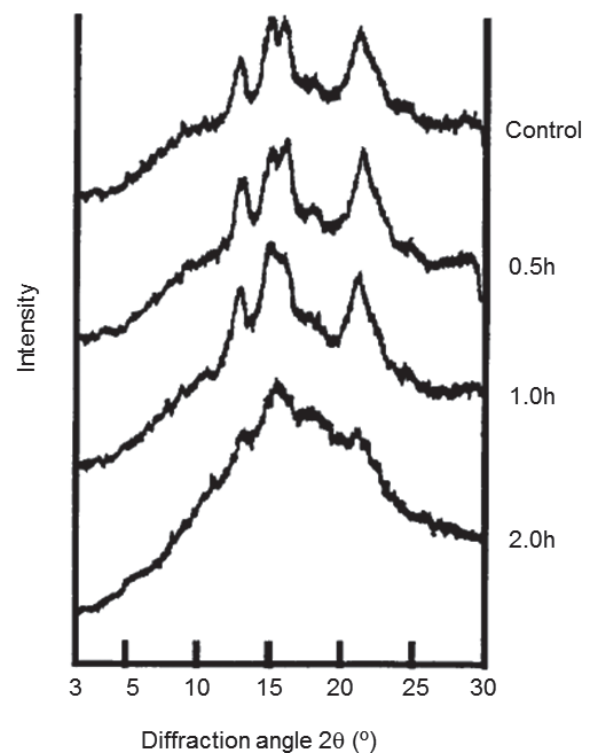

Fig. 1. X-ray diffraction patterns of heat treated wheat starch. 


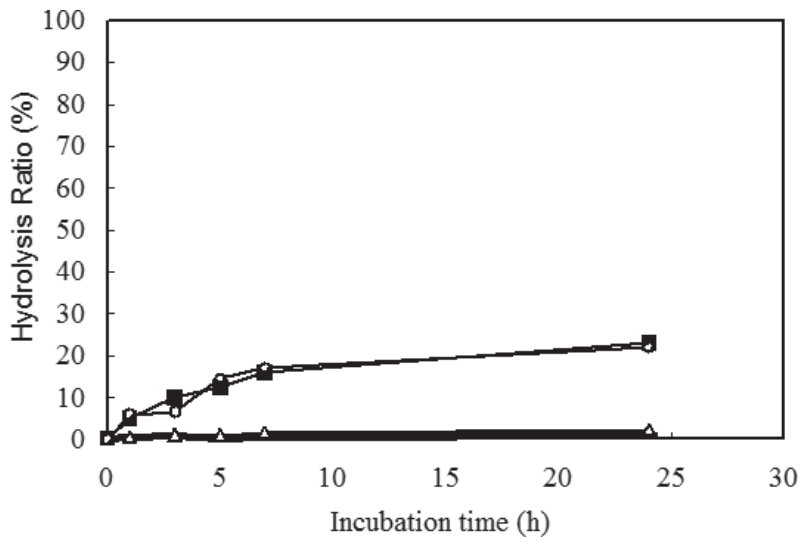

Fig. 2. Glucoamylase susceptibility of heat treated wheat starch.

-, Control; $\triangle, 0.5$ h; $\square, 1.0$ h; $\bigcirc, 2.0$ h.

ほとんど同じ分解率を示した。この值は，可溶性澱粉にお ける 24 時間後の分解率とほぼ同じであることから，1.0 時 間処理と 2.0 時間処理により可溶性澱粉並みの酵素感受性 が得られたと推察された。これらの結果から，1.0 時間以 上の乾熱処理により溶解度や膨潤度などがコントロールに 比べて大きく増加すると考えられた。そこで実際に膨潤度 の測定を行った結果，コントロールは $2.1 \mathrm{~mL} / \mathrm{g}$ dry starch, 0.5 時間処理は $2.1 \mathrm{~mL} / \mathrm{g}$ dry starch であったのに対し， 1.0 時間処理は $10.0 \mathrm{~mL} / \mathrm{g}$ dry starch, 2.0 時間処理は $11.0 \mathrm{~mL} / \mathrm{g}$ dry starch となり，乾熱処理 1.0 時間以上の澱粉で膨潤が 認められた。しかし, 顕微鏡観察から粒表面の崩壊はほと んどみられなかった。

\section{3) 示差走査熱量分析 (DSC) による糊化特性}

乾熱処理澱粉の示差走査熱量測定結果を Fig. 3 と Table 1 に示した。その結果，乾熱処理時間が長くなるほ ど糊化温度 $\left(T_{\mathrm{p}}\right)$ が低温側に移行し, エンタルピーもコン トロールに対して乾熱処理 0.5 時間では $76.1 \%$ であった が，乾熱処理 1.0 時間では $1.7 \%$ ，乾熱処理 2.0 時間では $0.0 \%$ に減少した。

湿熱処理においては，生澱粉に比べて糊化温度が高温側 に移行するという報告 ${ }^{11}$ があり，これは含有水分より結晶 性が改善されたためとされている。しかし，乾熱処理は澱 粉中の結晶領域に影響を与えるほどの水分がないことが示 唆される。また，1.0 時間処理ではほとんど吸熱ピークが

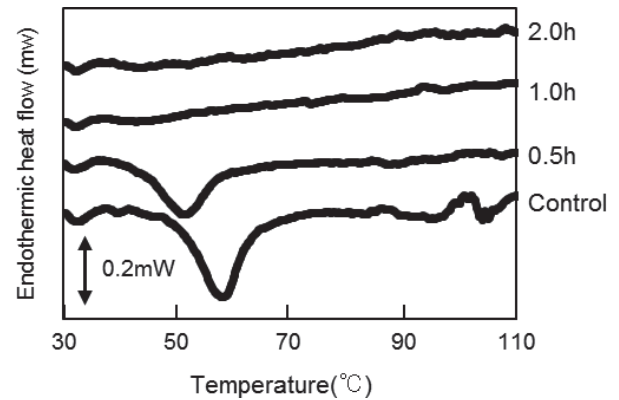

Fig. 3. Differential scanning calorimetry of heat treated wheat starch.
Table 1. DSC thermal properties of heat treated wheat starch.

\begin{tabular}{|c|c|c|c|c|c|c|}
\hline & \multicolumn{4}{|c|}{ Peak 1} & \multicolumn{2}{|c|}{ Peak 2} \\
\hline & $\begin{array}{l}T_{\mathrm{o}} \\
\left({ }^{\circ} \mathrm{C}\right)\end{array}$ & $\begin{array}{c}T_{\mathrm{p}} \\
\left({ }^{\circ} \mathrm{C}\right)\end{array}$ & $\begin{array}{c}T_{\mathrm{c}} \\
\left({ }^{\circ} \mathrm{C}\right)\end{array}$ & $\begin{array}{c}\Delta H \\
(\mathrm{~mJ} / \mathrm{mg})\end{array}$ & $\begin{array}{c}T_{\mathrm{p}} \\
\left({ }^{\circ} \mathrm{C}\right)\end{array}$ & $\begin{array}{c}\Delta H \\
(\mathrm{~mJ} / \mathrm{mg})\end{array}$ \\
\hline Control & 49.3 & 58.1 & 73.9 & $\begin{array}{c}10.42 \\
(100.0)\end{array}$ & 104.0 & 0.95 \\
\hline $0.5 \mathrm{~h}$ & 48.3 & 51.4 & 72.0 & $\begin{array}{c}7.93 \\
(76.1)\end{array}$ & 107.2 & 0.12 \\
\hline $1.0 \mathrm{~h}$ & 30.6 & 32.4 & 37.5 & $\begin{array}{c}0.18 \\
\left(\begin{array}{c}1.7 \\
)\end{array}\right.\end{array}$ & 97.7 & 0.23 \\
\hline $2.0 \mathrm{~h}$ & N.D. & N.D. & N.D. & $\left.\begin{array}{l}\text { N.D. } \\
0.0\end{array}\right)$ & N.D. & N.D. \\
\hline
\end{tabular}

DSC analysis condition: vial(Ag), $70 \mu \mathrm{L}$; sample, $15 \mathrm{mg}$; water, $45 \mu \mathrm{L}$; heating rate, $2^{\circ} \mathrm{C} / \mathrm{min}$. $T_{\mathrm{o}}$, onset temperature; $T_{\mathrm{p}}$, peak temperature; $T_{\mathrm{c}}$, conclusion temperature; $\Delta H$, enthalpy. ( ), Relative ratio to enthalpy of control.

みられず，2.0 時間処理では吸熱ピークは検出されなかっ たことから，1.0 時間以上の乾熱処理は，小麦澱粉の物理 的性質を大きく变化させ，糊化温度低下をもたらしたと考 えられる。しかし，粒子を顕微鏡観察してもほとんど変化 が起きていないことから，乾熱処理は，澱粉粒子の表面よ り内部に影響を与えるものと思われる。

\section{4) 極限粘度}

乾熱処理澱粉の極限粘度測定の結果を Table 2 に示し た。処理時間が長くなるほど低い值を示し，コントロール に対して 0.5 時間処理では半分以下の粘度を示した。 1.0 時間処理ではさらに低い值を示したが，2.0 時間処理では 1.0 時間処理と同一值であった。澱粉の希薄溶液はほぼ ニュートン流動を示し，その粘度は分子の大きさに比例す る ${ }^{12}$ ため，乾熱処理によって 0.5 時間処理で約 45\%，1.0 時 間および 2.0 時間処理では約 $19 \%$ の大きさにまで低分子 化されていることが示唆される。

\section{5) ラピッドビスコナライザー (RVA) による粘度特性}

乾熱処理澱粉の粘度特性をラピッドビスコアナライザー で測定した結果を Fig. 4 に示した。その結果，乾熱処理時 間が長くなるほど粘度が低下し，1.0 時間と 2.0 時間処理 では糊化時に起こる粘度上昇がほとんどみられなかった。 粘度は澱粉粒中のアミロペクチンが関与するといわれてい ることから，1.0 時間以上の乾熱処理により小麦澱粉中の アミロペクチンが分解されたことが示唆される。

Table 2. Intrinsic viscosity of heat treated wheat starch.

\begin{tabular}{cc}
\hline & Intrinsic viscosity $[\eta]$ \\
\hline Control & $1.681(100)$ \\
$0.5 \mathrm{~h}$ & $0.759(45)$ \\
$1.0 \mathrm{~h}$ & $0.322(19)$ \\
$2.0 \mathrm{~h}$ & $0.319(19)$ \\
\hline
\end{tabular}

( ), Relative ratio for intrinsic viscosity of control. 


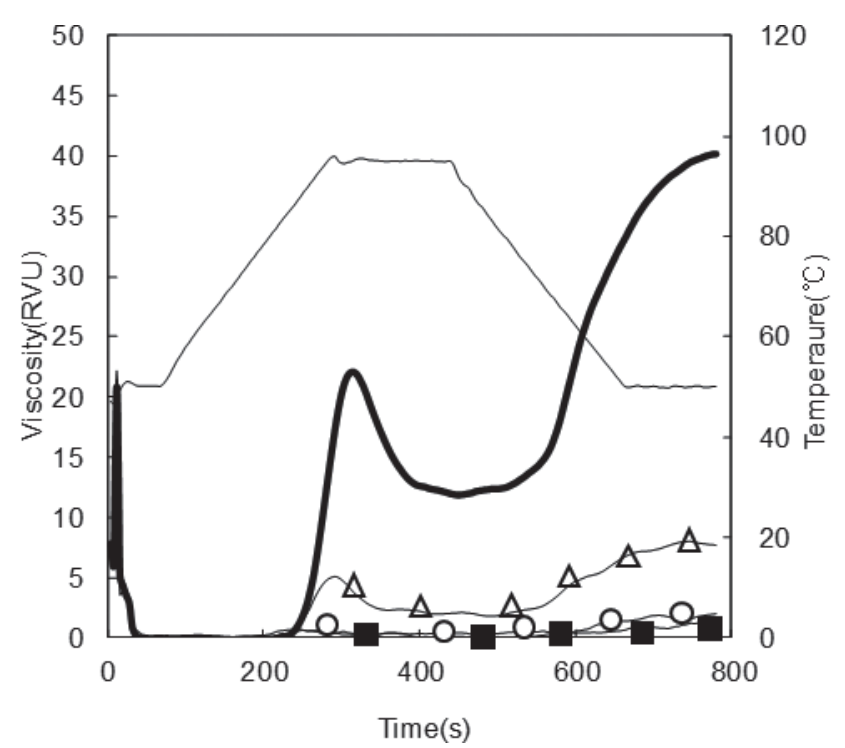

Fig. 4. Rapid viscogram patterns of heat treated wheat starch. -, Control; $\triangle, 0.5 \mathrm{~h} ; \mathbf{\square}, 1.0 \mathrm{~h} ; \bigcirc, 2.0 \mathrm{~h}$.

\section{3. 考察}

澱粉の糊化は基本的には水と熱による結晶領域の水和で あるが，水和とは広義に扔ける水への溶解と考えられる。 しかし, Donovan ${ }^{13}$ による研究で澱粉と水の比を縮小して いくと糊化温度が上昇して糊化という定義から外れた形に なる。すなわち，熱による結晶領域の融解である。澱粉の 湿熱処理は水蒸気のわずかな水と熱による結晶領域の再配 列化による現象とされており，糊化に至らなくても適度な 水と熱があれば澱粉の性質が大きく変化することは明らか である。本研究の澱粉の加熱条件は $200^{\circ} \mathrm{C}$ と湿熱処理より かなり高温であるため，澱粉自身が $12 \sim 14 \%$ 程度の水分 を保有していても，湿熱条件に適合する温度は極めて短時 間で通過するため湿熱処理に相当する澱粉の再配列化は起 きないと考えられる。このことは $200^{\circ} \mathrm{C} 0.5$ 時間処理で X 線回折図形でのピーク強度変化がみられないことからもい える。しかし， 2.0 時間処理でほぼピークが消滅している ことは, この時点で水の存在は考えられないことから, 結 晶領域が融解したことを意味している。

パンを焼成する場合, パン表面部分 (クラスト) は 230 ${ }^{\circ} \mathrm{C}$ で 20 分処理で $165^{\circ} \mathrm{C}$ 前後に達するが, この場合, 内部 (クラム) から絶えず水蒸気が供給されるため, 本研究の 乾熱処理と全く状況が異なる。澱粉の重量を測定するとコ ントロール (処理前) の $5,000 \mathrm{mg}$ が 0.5 時間処理で 4,488 $\pm 5.4 \mathrm{mg}, 1.0$ 時間処理で $4,481 \pm 5.3 \mathrm{mg}, 2.0$ 時間処理で $4,456 \pm 0.7 \mathrm{mg}$ に減少している。コントロールの水分は $12.1 \%$ なので, これを基に計算すると, コントロールの乾 物量は 4,395 mg で水分量は $605 \mathrm{mg}$ となる。加熱処理によ り水分量は 93 61 mg となり, わずかに残る程度である。 一方極限粘度の相対值は生澱粉を 100 とした場合, 0.5 時 間処理が $45,1.0$ 時間処理で $19,2.0$ 時間処理で 19 であ り, $[\eta]=\mathrm{kM}^{\alpha}$ で $\alpha$ は一般に $0.5 \sim 1.0$ とされ，澱粉では
0.7 前後とされている。この值は溶媒によって大きく動き, 特に本研究で用いた強アルカリ溶媒中ではグルコース残基 の水酸基はかなり解離していると考えられることから分子 の形も大きく変形しているはずである。しかし，あえて $\alpha$ を 0.7 と置き, 相対的分子量を計算すると, コントロール を 100 とした場合， 0.5 時間処理で $25.1 ， 1.0$ 時間処理で 9.5, 2.0 時間処理で 9.5 となる。したがって，1.0 時間処理 の時点では澱粉の熱による分解はほぼ終了していることに なる。ここで 0.5 時間処理で平均的に約 4 回の切断, 1.0 時間処理と 2.0 時間処理で平均的に 10.5 回の切断が計算上 起きていることになるが，コントロールのグルコース残基 当たりの水分子は当初 1.24 倍存在するので, この切断が 内部にあった水による加水分解と考えるに十分な水の量が 存在することになる。また，水がわずかにしか存在しない 1.0 2.0 時間の過程で計算上の分子量変化が起きていない ことは, この分解が加水分解であることを示唆していると も考えられる。では，分解がどの領域で起きているかを考 えると, X 線回折図形が 1.0 時間処理で完全に保持されて いるにもかかわらず分解がその時点でかなり進んでいるこ とから, 分解は非結晶領域で主として起きたと推定され る。そして，その後熱により結晶領域の融解が進んだと考 えられる4。

パンのクラストの褐変は共存するタンパク質や還元糖に よるメイラード反応であるが，澱粉はこの条件下でどれく らいメイラード反応が起こっているのかを示すのは難しい ことからも, 加水分解以外の反応は考えにくい。熱分解に 関する研究は木炭製造に絡んで行われているが，200 C を はるかに超えた温度領域での反応を取り扱っているため, 本研究の参考にならない。また, 酵素の最大分解率が $23 \%$ の結果と, 分岐鎖の非還元末端からグルコース単位 で順次切断する酵素作用形式を考え併せると, 乾熱処理に より加水分解的切断でかなりの低分子化が起きているにも かかわらず, 脱水反応に伴う副反応 (アンヒドロ糖生成や 架橋生成) が起きた可能性も示唆されるが，これの検出は

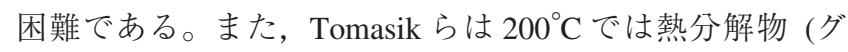
ルコースの断片化やカルボニル化合物の生成) がほとんど 検出されていないと述べている。

\section{4. 要約}

以上, $200^{\circ} \mathrm{C}$ における小麦澱粉の乾熱処理により，0.5 2.0 時間の処理時間では港粉粒の表面には変化がみられず, マクロ的な影響は与えなかったが，1.0 時間以上処理する ことにより糊化特性や粘度に大きな影響を与えた。しかし 1.0 時間処理でも結晶性はほぼ保持していた。1.0〜2.0 時 間処理の糊化特性や粘度からかなり低分子化されているこ とが示唆され, 熱による結晶領域の崩壊が起きているので はないかと推察される。 
謝辞

本研究を遂行するにあたり，再測定に協力して頂きまし た。Sasicha Chensom (タイ・スラナリー工科大学) に深謝 申し上げます。

\section{文献}

1) 白川武志：デンプンの乾熱処理について 殺菌効果とゼ リー強度への影響. 香川県発酵食品試験場報告，74，4751 (1981).

2 ) 篠田和雄, 高橋 徹, 金 哲, 三浦 靖, 小林昭一: 乾 熱処理および湿熱処理がきび粉の物理特性に及ぼす影響. 食科工，49，491-499 (2002).

3 ) 高橋 徹, 篠田和雄, 三浦 靖, 金哲, 小林昭一 : 加 熱処理が米粉の物理化学的特性に及ぼす影響. 食科工, 49, 757-764 (2002).

4 ) P. Tomasik and S. Wiejak: The thermal decomposition of carbohydrates. Part II. The decomposition of starch. Adv. Carbohydr. Chem., 47, 279-343 (1990).

5 ) 伊藤友美，安達卓生，山田哲也：クッキー様菓子中の澱粉
特性に及ぼす各種油脂の影響。食科工，55，56-62 (2008).

6 ) 伊藤友美, 安達卓生, 小原章裕, 山田哲也：各種モノグリ セリド中で加熱処理した澱粉の特性. 食科工，55，589596 (2008).

7 ) S. Hizukuri, Y. Takeda and M. Yasuda: Multi-branched nature of amylose and the action of debranching enzymes. Carbohydr. Res., 94, 205-213 (1981).

8 ) 後藤富士雄：澱粉ノリのレオロジー的性質の測定法.「澱 粉科学ハンドブック」，二國二郎監修，朝倉書店，東京， pp. 223-224 (1977).

9 ) T. Ito, T. Adachi, M. Kojima and T. Yamada: Effect of surfactant addition on viscosity profiles of starches Part 2 effect of temperature elevating rate on viscosity. Sci. Rep. Fac. Agric. Meijo Univ., 41, 29-39 (2005).

10) K. Fukami, K. Kawai, T. Hatta, H. Taniguchi and K. Yamamoto: Physical properties of normal and waxy corn starches treated with high hydrostatic pressure. J. Appl. Glycosci., 57, 67-72 (2010).

11) E. Miyoshi: Effect of heat-moisture treatment and lipids on gelatinization and retrogradation of maize and potato starches. Cereal Chem., 79, 72-77 (2002).

12) 前田 嚴：希薄溶液の粘度.「澱粉関連糖質実験法」, 中村 道徳，貝沼圭二編，学術出版センター，東京，pp. 173-174 (1986).

13) J.W. Donovan: Phase transitions of the starch-water system. Biopolymers, 18, 263-275 (1979). 